\title{
THE CONTRACEPTIVE ACTION OF IMPEDING OESTROGENS
}

\author{
V. CONTRACEPTIVE ACTION OF OESTRIOL THROUGH \\ SEMINAL TRANSFER DURING MATING
}

\author{
A. SGUBLINSKY AND H. H. WOTIZ \\ Department of Biochemistry, Boston University School of Medicine, \\ Boston University Medical Center, Boston, Massachusetts, U.S.A.
}

(Received 4th fune 1970)

Earlier reports from this laboratory (Scublinsky \& Wotiz, 1971; Wotiz \& Scublinsky, 1971) clearly demonstrated the antioestrogenic and correlated antifertility action of oestriol. Since this activity also occurred post coitum, the possibility that contraception may occur by direct transfer of oestriol to the vicinity of the uterus by way of the semen was investigated. The local action of semen-transported oestrogens has already been reported by Ericsson \& Baker (1966), and has since been verified by Banerjee (1968).

Three groups of five male 300-g Sprague-Dawley rats were treated by injection for 3 days with saline, $1 \mathrm{mg}$ of oestriol in $0.5 \mathrm{ml}$ of sesame oil, and $2 \mathrm{mg}$ of oestriol in $0.5 \mathrm{ml}$ of sesame oil, respectively. After 3 days of treatment, each of the males was mated with a mature female rat in pro-oestrus. Microscopic examination of the spermatozoa in the vaginal smears from all animals never showed any headless spermatozoa, though this abnormality was reported by Ericsson \& Baker (1966) to occur when oestradiol was injected into male rats. Ten days after proven mating, each female was killed and the uterus examined for implantation sites.

Thirty days after the first mating, the ten treated males were again mated with mature females and were then killed. The testes from these ten rats were fixed in formalin and histological preparations were made. Ten days after this mating, the second group of females were killed and their uteri examined as before.

Table 1 shows the results obtained from the first part of the experiment. With doses of $1 \mathrm{mg}$ of oestriol/day, $80 \%$ effective contraception was observed. When the dose was doubled, full contraceptive activity was obtained.

The treatment did not appear to damage the testes or spermatozoa since all spermatozoa observed in the vaginal smears appeared normal and the test animals were able to impregnate females 30 days after treatment. Histological examination of the testicular tissue, epididymis and vas deferens showed no morphological changes nor did spermatogenesis appear to be in any way altered from examinations of the tubules.

Thus, it seems reasonable to conclude that contraception occurred as a 
consequence of transport of oestriol by the semen to the uterus, rather than through inhibition of spermatogenesis.

It is interesting to compare the dosages required for contraception by oestradiol and oestriol. Banerjee (1968) used $1 \mathrm{mg}$ of oestradiol for 10 days to achieve complete contraception, while the same result was observed here with twice the dose of the very much weaker uterotrophic substance, oestriol, given for only 3 days. This suggests that, while oestradiol seems to work by accelerating the movement of ova through the oviduct thus preventing implantation, it is conceivable that oestriol, which acts as an anti-oestrogen (Wotiz \& Scublinsky, 1971), inhibits the necessary endometrial stimulation by oestradiol.

TABLE 1

CONTRAGEPTIVE EFFEGT OF TRANSMITTED OESTRIOL

\begin{tabular}{c|c|c|c|c|c}
\hline Group & Animals & Treatment & $\begin{array}{c}\text { No. of } \\
\text { females pregnant } \\
\text { following mating }\end{array}$ & $\begin{array}{c}\text { Average no. of } \\
\text { implantations } \\
\text { per horn }\end{array}$ & $\begin{array}{c}\text { No. of } \\
\text { implantations: } \\
\text { second mating }\end{array}$ \\
\hline 1 & 5 & Saline & 5 & $7 \cdot 8$ & - \\
2 & 5 & $1 \mathrm{mg}$ oestriol & 1 & $6 \cdot 0$ & $7 \cdot 8$ \\
3 & 5 & $2 \mathrm{mg}$ oestriol & 0 & 0 & $7 \cdot 5$ \\
\hline
\end{tabular}

This investigation was supported by research grant CA-03135, training grant HD-00217, and by a Research Career Development Award 5-K3-GM15,369 from the United States Public Health Service, National Institutes of Health, Bethesda, Maryland; and a Bio-Medical Fellowship from The Population Council, New York.

Taken in part from a doctoral dissertation to be presented to the Boston University Graduate School.

\section{REFERENCES}

BANERJEE, B. N. (1968) The effect of oestrogen on the fertility of the rat when transferred through the semen during mating. F. Reprod. Fert. 17, 157.

ERICsson, R. J. \& BAKER, V. F. (1966) Transport of oestrogens in semen to the female rat during mating and its effect on fertility. F. Reprod. Fert. 12, 381.

Scurblinsky, A. \& Wotiz, H. H. (1971) The contraceptive action of impeding oestrogens. I. Activity of oestriol. F. Reprod. Fert. 26, 139.

Wotrz, H. H. \& Scublinsky, A. (1971) The contraceptive action of impeding oestrogens. II. Post-coital effect of oestriol. F. Reprod. Fert. 26, 143. 